Article

\title{
Greenwash and Green Purchase Intention: The Mediating Role of Green Skepticism
}

\author{
Thi Thu Huong Nguyen ${ }^{1,2, *}$, Zhi Yang ${ }^{1}$, Ninh Nguyen ${ }^{3}{ }^{1}$, Lester W. Johnson ${ }^{4}$ \\ and Tuan Khanh Cao ${ }^{5}$ \\ 1 School of Business Administration, Hunan University, Changsha 410082, China; yangmkt@hnu.edu.cn \\ 2 Faculty of Business Administration, Hanoi University of Industry, Hanoi 100000, Vietnam \\ 3 Department of Entrepreneurship, Innovation and Marketing, La Trobe Business School, La Trobe University, \\ Bundoora, VIC 3086, Australia; ninh.nguyen@latrobe.edu.au \\ 4 Department of Management and Marketing, Swinburne Business School, Swinburne University of \\ Technology, Hawthorn, VIC 3122, Australia; lwjohnson@swin.edu.au \\ 5 Faculty of Marketing, Thuongmai University, 79 Ho Tung Mau Road, Hanoi 100000, Vietnam; \\ khanhct@tmu.edu.vn \\ * Correspondence: thuhuong@haui.edu.vn; Tel.: +86-156-1619-1933
}

Received: 18 April 2019; Accepted: 6 May 2019; Published: 9 May 2019

\begin{abstract}
Along with the acceleration of green marketing in recent years, greenwash has been utilized by firms to get ahead of their rivals. Underpinned by the cognition-affect-behavior (C-A-B) paradigm, this study examines a model linking greenwash and green skepticism with green purchase intentions. It also investigates the moderating role of information and knowledge on the relationship between greenwash and green purchase intentions. Data were obtained from 419 Vietnamese consumers who had been involved in purchasing green vegetables using an online survey. Multivariate data analysis demonstrated that greenwash was negatively associated with green purchase intentions and that green skepticism mediated this negative association. In addition, the moderating effect of information and knowledge was confirmed. These findings enrich the extant knowledge on the relationship between greenwash and green purchase intentions. They also have important implications for firms that aim to reduce consumers' skepticism and increase their intentions to purchase green food.
\end{abstract}

Keywords: greenwash; green skepticism; green purchase intentions; information and knowledge; green marketing; green food

\section{Introduction}

In recent decades, the trend of environmental protection and green marketing has brought changes in consumer demand and behavior. Consumers are more interested in eco-friendly lifestyles because they are not only environmentally responsible but they also expect personal benefits from green products [1]. Green initiatives are available in many areas such as green energy, food, tourism, packaging, fashion, architecture, government, and green buildings [2]. However, some corporates have adjusted their green business strategies using the idea that greenwashing (i.e., pretending to be green) is only about talking and not doing [3-6]. These corporates have provided ambiguous environmental claims and misled consumers about their environmental practices. The wide spread greenwashing practices can be accounted for by several major reasons. Notably, not all firms have enough capabilities to undertake green marketing strategies [7]. Besides, greenwashing helps firms gain potential benefits or reputational capital [8] or to reduce expenses [9]. Furthermore, greenwashing may even trigger pressure from stakeholders $[10,11]$. Thus, many companies seem to present themselves as green firms despite not really being green. 
In the previous literature, there have been many studies concerning causes, taxonomy, and consequences of greenwashing behaviors in several different industries such as the gas industry [12-14], automobile industry [6], finance industry [15,16], hospitality industry [9,17-19], education industry [20], electronics industry [7,21-23], etc. However, there are few studies on greenwash behavior in the food industry, particularly in developing countries. To the best of our knowledge, there has been no quantitative work examining the relationship between greenwashing and green purchase intentions, incorporating the mediating role of green skepticism and the moderating role of information and knowledge. Virtually all past research has been conducted in Western countries, particularly in the United States or Europe [3,7,14,22,24-34]. Therefore, our study is an effort to partly fill this gap.

To extend the extant literature, this study focuses on the food industry in Vietnam, which has become one of the fastest-growing countries in Asia. Vietnam is a potential market for organic and green food [35,36]. The latest data from the World Bank [37] reveal that Vietnam's population is 95.5 million and the gross domestic income is $\$ 223.78$ billion. Furthermore, Vietnamese people spend approximately half of their income on food and beverage products [38]. Vietnam food quality and safety has drawn increasing attention from consumers, corporations, and stakeholders $[35,36]$. However, many food companies seem to modify their business strategies in response to green demands from customers. These companies misuse pesticides in agriculture [39], use contaminated water, fertilizer, and soil [40], use contaminated washing water post-harvest [41], and improperly use food additives [42]. While many younger consumers have concern for environmental issues as well as psychological health [43], there are also a large number who have limited and superficial perceptions of green products [44]. Moreover, the fact of environmental protection meets difficulties because of restricted greenwashing regulation and uncertain implementation of this regulation. Remarkably, there is a lack of national regulations on organic and green labels for food products [35]. Thus, many food companies misuse greenwashing to appear to be environmentally friendly. For example, several food manufacturers and retailers in big cities such as Hanoi and Ho Chi Minh City use organic labels for their products but fail to provide evidence that such products meet the organic food criteria [45]. It is also observed that many farmers in Bac Giang province who claim to apply good agricultural practices use fertilizers and pesticides in growing their produce [46]. Consequently, the demand for green products is expected to continue but customers still worry about the contrast between image and reality. They still might doubt the green foods' claims.

There is growing consumer skepticism towards companies that take opportunistic advantage of the green movement. These firms occasionally use greenwashing to promote their environment-friendly behavior without fully divulging destructive information in order to build up encouraging association images [13,14,17,47-49]. Meanwhile, consumer insights of greenwashing exist and their influence on brand attitudes and buying intention is significant. Consumers' information and knowledge on green products is relatively important for consumers making eco-friendly purchasing decisions [50]. The purpose of this study is therefore threefold. First, the present study proposes and investigates a theoretical model that relates perceptions of greenwashing to green skepticism and green purchase intention. Second, based on a review of related literature, this study examines the mediation effects of green skepticism as well as the moderating effects of information and knowledge in the relationship between greenwashing and green purchase intentions. Third, it provides fresh insights into the emerging market context and potentially important information for both academicians and specialists about greenwashing behaviors in green marketing. Importantly, the findings of this study can expectedly help companies enhance consumers' green purchase intentions under the circumstance of the high number of greenwashing cases.

The main content of the paper is organized as follows. The literature review and hypotheses are presented in Section 2. In Section 3, the research methodology including research measures and data collection is described. The empirical results are presented and explained in Section 4. This is followed 
by Section 5 discussing the key findings and implications. Finally, the limitations and suggested future work are presented in Section 6.

\section{Literature Review and Hypotheses}

\subsection{Greenwashing Phenomenon in the Food Industry}

In recent years, food production and consumption has been one of the major causes of global environmental degradation [51]. Although the food industry has begun to implement various environmentally responsible programs [52,53], not every company has integrated environmental concerns into business values. Many companies communicate that they adopt eco-friendly practices to cover their true activities. Lyon and Maxwell refer to greenwashing as "selective disclosure of positive information about a company's environmental or social performance without full disclosure of negative information on these dimensions, so as to create an overly positive corporate image" [47] (p. 9).

In the food industry, different certifications are available but are not well known to the majority of people. Examples are Animal Welfare Approved, Bird Friendly, Humane Farm Animal Care, Marine Stewardship Council, Salmon-Safe, and USDA Organic. Some authors have found that competing labels and environmental practices of firms create consumer confusion and allow space for opportunistic use of greenwashing $[49,54]$. Authorization to externally defined standards is often believed to be a resolution to the problem of greenwashing that substitutes the trustworthiness of a third-party authorizer for a firm's own rights. However, while authorizations on both the product level and the company level bring some capacity in controlling greenwashing, it cannot prevent the phenomenon overall. Firms wish to lobby for the introduction of a third-party eco-labeling system or stricter labeling rules [55]. One possible issue with product-level ecolabels is that they can be susceptible to fraud by dishonest manufacturers [56]. Under these circumstances, customers doubt the environmental qualities of green food. Though the subject of greenwashing has been examined in various industries in developed countries, it remains fairly under-researched in the food industry in emerging markets.

\subsection{Approaches to Studying Greenwashing}

Previous research has used different methodological approaches to studying greenwashing, which has been conceptualized as selective disclosure, attention deflection, deceptive manipulation, ineffective public voluntary programs or dubious authorization and labels [6,56-58]. According to Lyon and Montgomery [49], research adopting qualitative approaches has applied case studies, ethnographies, narrative, interviews, and discourse analysis, whereas quantitative studies have used surveys, simulations, experimental studies, and large data sets. In addition, some studies conducted content analysis on both qualitative and quantitative data [6]. Such data can be collected from corporate reports, manager interviews, newspapers, advertising, and websites [6,49]. Essentially, prior studies investigating the impacts and consequences of greenwash behaviors often use the deductive survey method to collect quantitative data from consumers [21,22]. This method enables researchers to test and validate models illustrating the interrelationships between greenwashing and various variables such as mediators and outcome variables $[21,22,59]$.

\subsection{The Cognition-Affect-Behavior (C-A-B) Paradigm}

This study employs the cognition-affect-behavior (C-A-B) paradigm to get a deeper understanding of the relationship between greenwashing and intention to green purchase. The C-A-B paradigm suggests that cognition (C) determines affect (A) which, in turn, influences behavior (B). Authors such as Nicosia [60], Howard and Sheth [61] used the C-A-B scheme to develop systematic models of consumer behavior. The C-A-B examines the reason for behavior through the individual's cognition and is very useful in explaining the mediating effect of emotions [62]. The C-A-B has been used to evaluate 
brand selection processes [63] and shopping experience [64]. It is an antecedent of some theories such as buyer behavior [61], appraisal theories of emotion $[65,66]$ and the consciousness-emotion-value model [67]. By studying green consumption in Vietnam in light of this framework, we figured out that consumers' cognitive knowledge is being influenced in line with the acceleration of greenwashing actions in the food industry, which brings about their skepticism of the green food's claims. As a result, it affects the green purchase intentions. Therefore, it is necessary to consider factors which may affect consumers' greenwashing cognitions leading to negative product judgment and lower purchase intentions. The present study models, on the base of C-A-B paradigm, the mediating role of green skepticism and the moderating role of information and knowledge in the nexus between greenwashing and the purchase intentions of green products.

\subsection{Greenwash and Green Purchase Intentions}

There is growing demand for food quality labels in emerging markets like Vietnam [68]. Several labels exist in the domestic food market, e.g. Vietnamese Good Agricultural Practices (VietGAP), Hazard Analysis and Critical Control Points (HACCP), and Global Good Agricultural Practices (GLOBALG.A.P.) However, consumers have trouble distinguishing between true and misleading claims. They even perceive high risk towards a green product. On the one hand, most companies in the food industry are strongly polluting but regularly advertise their eco-friendly images. On the other hand, retailers that advertise green products but do not explain how such products contribute to the quality of the environment are likely looked upon with skepticism. The negative effect of this is distrust about these labels $[69,70]$. Thus, customers worry about the contrast between image and reality, so they doubt the green claims [33,71]. Polonsky et al. [72] showed that greenwash brings fake green claims to the market and would lessen the popularity of real green products. Customers would disbelieve all green product ideas, and consequently the green movement would lack the support of stakeholders, enterprises, customers, and society as well as organizations who would bear reduction in the green consumption market share [32]. Ramus and Montiel [73] and Chen et al. [22] demonstrated that greenwash can create negative impact on word-of-mouth, green perceived quality and green satisfaction and it would decrease consumer belief. Furthermore, Nyilasy et al. [34] stressed that corporates' greenwash behavior is not merely an ethical issue but also the negative impact of consumer's perception. This has a real and detrimental effect on brand attitudes and green purchase intentions, even though occasionally, customers are unable to identify the truth and the misleading action [34]. Based on this literature review, the following hypothesis is formulated:

Hypothesis H1. Greenwash has a negative effect on green purchase intentions.

\subsection{Greenwash and Green Skepticism}

Green skepticism appears to be a current topic for consumers, corporations, and stakeholders. Generally, skepticism denotes an individual's tendency to doubt, disbelieve, and question [74,75]. Furthermore, skepticism relates to notions such as cynicism, suspicion, low trust, and distrust. In recent years, along with the rapid expansion of the market for eco-friendly products, instances of greenwashing have proliferated tremendously $[30,76]$. Although environmental safety rules are being put in place environmental regulations are not being well applied [31]. Consumers' recognition of greenwashing exists, which leads to their skepticism about firms' green initiatives [21,33]. Thus, the following is hypothesized:

Hypothesis H2. Greenwash has a positive effect on green skepticism. 


\subsection{Green Skepticism and Green Purchase Intentions}

One of the most important barriers affecting purchase decision is consumer skepticism with regard to organic products being of higher quality [77]. Consumers deliberate whether to buy or not when they appear to perceive differences between green foods and conventional foods in terms of credence attributes such as taste, freshness, and functional performance, appearance, price, quality, and convenience [78-80]. In Vietnam, most companies in the food service industry are severely polluting but regularly advertise their eco-friendly images. Thus, customers worry about the contrast between image and reality. Consumers may grow doubtful when they realize discrepant green advertising and corporate performance [34]. Consumers can start to make negative assertions about the company motives. As consumers are skeptical about the green claims, they even may stop buying the green product [81]. Thus, it is hypothesized that:

Hypothesis H3. Green skepticism has a negative effect on green purchase intentions.

\subsection{The Mediating Role of Green Skepticism}

Prior studies demonstrate that greenwashing leads to skepticism about green claims [21,71]. When consumers are skeptical about a firm that takes opportunistic advantage of environmental trends, they hold negative attitudes towards the firm brand and tend not to purchase the firm's products [2,82]. In addition, the C-A-B paradigm suggests the mediating effect of green skepticism on the association between greenwash and green purchase intentions. This leads to the formulation of the following hypothesis:

Hypothesis H4. Green skepticism mediates the relationship between greenwash and green purchase intentions.

\subsection{The Moderating Role of Information and Knowledge}

Information and knowledge of green products can influence purchase decisions [83-85]. Information and knowledge influencing the consumer decision-making process include details about products' attributes, health effects, economic value, and environmental benefits that can be generated in the medium-and long-terms [50]. In general, consumers tend to search for information about green products and their associated values [86].

Consumers often have difficulties in comparing green foods against conventional foods and evaluating how purchasing eco-labelled products addresses specific environmental issues. Notably, consumers, when analyzing green products, are likely to view information about environmental, health and safety issues as an additional attribute of these products [50]. Several studies reveal that health is the key motivator for consumers to select eco-labelled products [87,88]. For these reasons, consumers embrace products that can be green substandard despite knowing the potential consequences of greenwashing. Therefore, this research suggests the moderating impact of information and knowledge on the relationship between greenwash and green purchase intentions. Hence, it is hypothesized that:

Hypothesis H5. The negative effect of greenwash on green purchase intentions is stronger for consumers whose information and knowledge is high compared to low.

Thereby, our proposed model is illustrated as shown in Figure 1. 


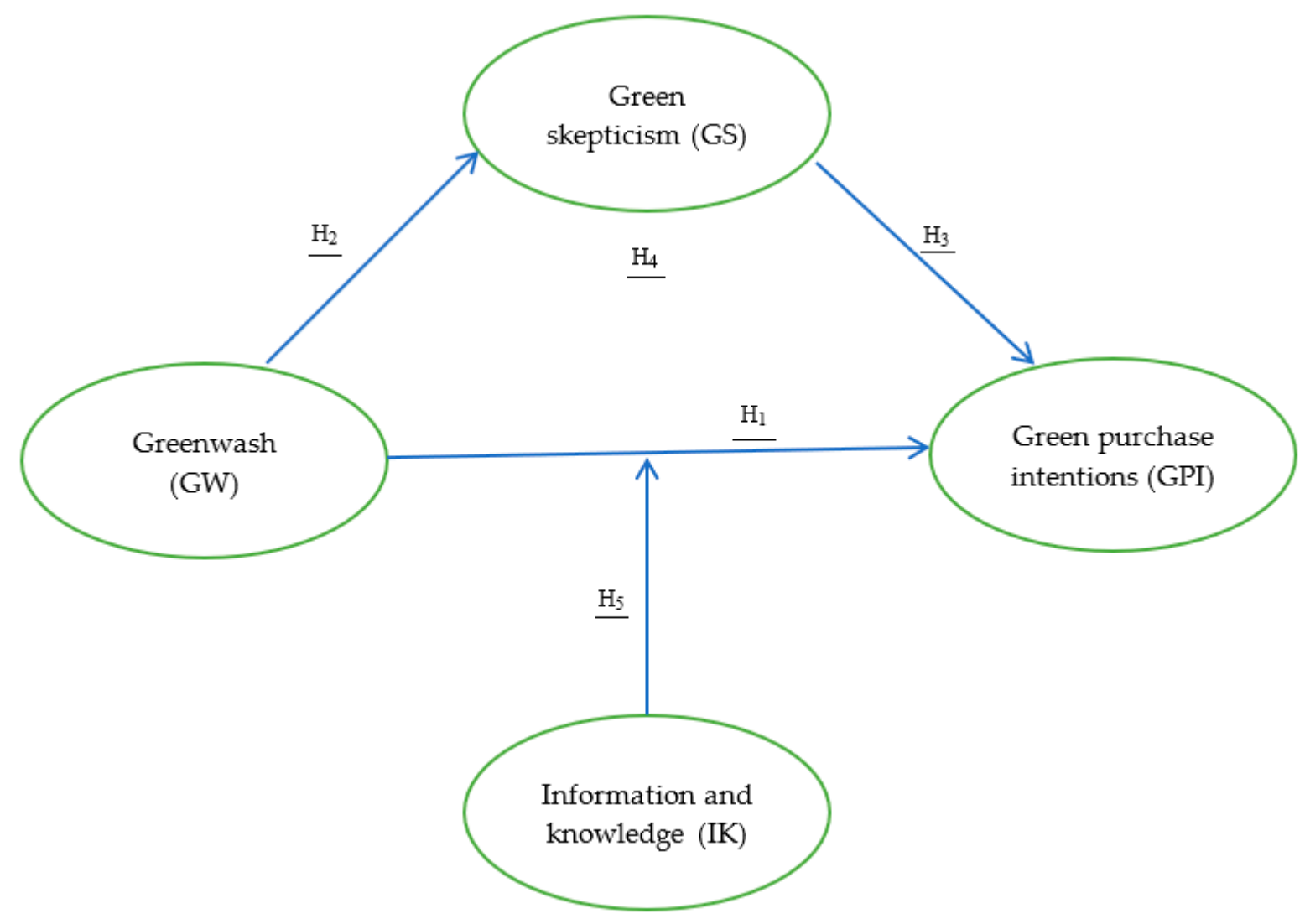

Figure 1. Research framework.

\section{Research Methodology}

\subsection{Research Measures}

The questionnaire was designed to assess consumers' response to corporates' greenwash behavior under the mediating role of green skepticism and the moderating effect of information and knowledge. The questionnaire was verified by linguistic experts to ensure its validation and fit for consumers in Vietnam. Additionally, the questionnaire was tested in classic pre-tests by chosen Vietnamese scholars. The review process of this investigation made the final question sheet more comprehensible from the respondent's perspective. The questionnaire began with a short description of the definition of green vegetables, the enterprise's green claims, and suggested that now many food companies seem to present themselves as green firms despite not being really green. Then, this study used two questions to ascertain the respondents who had been working and experiencing buying green vegetables. Eventually, the final questionnaire was fully approved after drawing opinions from experts. All variables were measured by a five-point Likert scale (anchored at 1 indicates "strongly disagree", 2 "disagree", 3 "neutral", 4 "agree", and 5 "strongly agree"). Following Horiuchi et al. [33] and Laufer [89], a five items measurement scale was used to measure greenwash. A four items green skepticism scale was adopted from Mohr et al. [90]. A four items green purchase intentions scale was adopted from Ajzen and Fishbein [91], Taylor and Todd [92], Mostafa [93], and Chen and Chang [94]. Additionally, a five items information and knowledge scale was adopted from Lai [95]; Spangenberg et al. [86]; Leire and Thidell [50], and Tseng and Hung [85]. 


\subsection{Data Collection}

This sample involved Vietnamese consumers who have experience in buying green vegetables. Data collection was conducted in collaboration with Vietnamese colleagues and associations. Respondents were invited by email and through social media to click on a link to a web page containing the questionnaire. We got 466 responses after two weeks but only a total of 419 responses was empirically examined because of removing deficient responses and extreme outliers. A number of $63.7 \%$ were from women and $36.3 \%$ from men; $44.2 \%$ were under 30 years old, $42.5 \%$ were aged from 31 to 45 years old, $13.3 \%$ were aged 46 and over; $88.5 \%$ were graduated with bachelor/ master/ doctor degrees and $86.9 \%$ had personal average monthly income from 5 million VND and over.

\subsection{Data Analysis}

The study employed SEM to investigate the proposed model [96]. As a general rule, the ratio of sample size to free model parameters should be at least five observations to one free parameter $[97,98]$. Our study contains 18 sample variables and 419 effective observations, which are greater than the above guidelines for minimum sample size for SEM. We also performed the bootstrap confidence intervals method to analyze the mediating role of green skepticism and utilized the analyzing measurement invariance to test for the moderating effect of information and knowledge. The data analysis was completed with SPSS and AMOS version 23 [IBM, USA].

\section{Results}

\subsection{Measurement Model}

Before testing the hypotheses, we used Cronbach's $\alpha$ coefficients to assess the reliability for each of the constructs. Table 1 shows that, factor loadings of indicators ranged from 0.633 to 0.901 (greater than 0.6) and Cronbach's $\alpha$ range from 0.771 to 0.911 (higher than 0.7) [99]. Thus, the Cronbach's alpha coefficient of all constructs presented in the research model are acceptable in reliability.

Then, we evaluated the discriminant validity of the overall measurement model. The Average Variance Extracted (AVE) was used to check discriminant validity [100]. Table 2 shows that the square root of AVE for each construct (diagonal elements in bold) is higher than the correlations among constructs in the model. Therefore, the measurement has good discriminant validity. Besides, each AVE is higher than 0.5 which confirms strong support for convergent validity of the scales. These results demonstrate the reliability and validity of the proposed model.

\subsection{Hypothesis Testing}

SEM was implemented to investigate the various hypotheses discussed above. A goodness of fit test is shown in Figure 2. The degree of fit of the model was demonstrated by the values of GFI (Goodness-of-fit index), NFI (Normed fit index), and CFI (Comparative fit index) indicators which respectively were $0.908,0.934$, and 0.961 , besides RMSEA (Root mean square error of approximation) is 0.045. According to Bagozzi and Yi [101], all fit indices met satisfactory levels. Furthermore, the results show that greenwash is negatively related to green purchase intentions with a standardized path coefficient of $-0.184 *(p<0.05)$, supporting $\mathrm{H}_{1}$. But greenwash is positively related to green skepticism with a standardized path coefficient of $0.215 *(p<0.05)$, supporting $\mathrm{H}_{2}$. Moreover, the results demonstrate that green skepticism has a negative effect on green purchase intentions with a standardized path coefficient of $-0.176^{*}(p<0.05)$, supporting $\mathrm{H}_{3}$. 
Table 1. Constructs' properties and items' loadings $(\lambda)$.

\begin{tabular}{|c|c|c|c|c|}
\hline $\begin{array}{l}\text { Constructs } \\
\text { (references) }\end{array}$ & Items & $\lambda$ & $\alpha$ & AVE \\
\hline \multirow{5}{*}{$\begin{array}{c}\text { GW } \\
\text { (Horiuchi et al. [33] and } \\
\text { Laufer [89]) }\end{array}$} & $\begin{array}{l}\text { Green vegetable misleads with words in its } \\
\text { environmental features. }\end{array}$ & $0.759 * *$ & \multirow{5}{*}{0.911} & \multirow{5}{*}{0.658} \\
\hline & $\begin{array}{l}\text { Green vegetable misleads with visuals or } \\
\text { graphics in its environmental features. }\end{array}$ & $0.758^{* *}$ & & \\
\hline & $\begin{array}{l}\text { Green vegetable possesses a green claim that is } \\
\text { vague or seemingly un-provable. }\end{array}$ & $0.849^{* *}$ & & \\
\hline & $\begin{array}{l}\text { Green vegetable overstates or exaggerates how } \\
\text { its green functionality actually is. }\end{array}$ & $0.853 * *$ & & \\
\hline & $\begin{array}{l}\text { Green vegetable leaves out or masks important } \\
\text { information, making the green claim sound } \\
\text { better than it is. }\end{array}$ & 0.831 & & \\
\hline \multirow{4}{*}{$\begin{array}{c}\text { GPI } \\
\text { (Ajzen and Fishbein [91], } \\
\text { Taylor and Todd [92], } \\
\text { Mostafa [93] and Chen and } \\
\text { Chang [94]) }\end{array}$} & $\begin{array}{l}\text { I will consider buying green vegetables because } \\
\text { they are less polluting in coming times. }\end{array}$ & 0.770 & \multirow{4}{*}{0.893} & \multirow{4}{*}{0.665} \\
\hline & $\begin{array}{l}\text { I will consider switching to environmental } \\
\text { friendly green vegetables for health reasons. }\end{array}$ & $0.901 * *$ & & \\
\hline & $\begin{array}{l}\text { I definitely want to purchase green vegetables } \\
\text { in the near future. }\end{array}$ & $0.871^{* *}$ & & \\
\hline & $\begin{array}{l}\text { I would also recommend others to buy green } \\
\text { vegetables. }\end{array}$ & $0.705 * *$ & & \\
\hline \multirow{4}{*}{$\begin{array}{c}\text { GS } \\
\text { (Mohr et al. [90]) }\end{array}$} & $\begin{array}{c}\text { Most environmental and safe claims made on } \\
\text { green vegetable package labels or in } \\
\text { advertising are true. }\end{array}$ & 0.780 & \multirow{4}{*}{0.874} & \multirow{4}{*}{0.642} \\
\hline & $\begin{array}{c}\text { Because environmental and safe claims are } \\
\text { exaggerated, consumers would be better if } \\
\text { such claims on green vegetable package labels } \\
\text { or in advertising were eliminated. }\end{array}$ & $0.824^{* *}$ & & \\
\hline & $\begin{array}{c}\text { Most environmental and safe claims on green } \\
\text { vegetable package labels or in advertising are } \\
\text { intended to mislead rather than to inform } \\
\text { consumers. }\end{array}$ & $0.795 * *$ & & \\
\hline & $\begin{array}{l}\text { I do not believe in most of the environmental } \\
\text { and safe claims made on the green vegetable } \\
\text { package labels or in advertising. }\end{array}$ & $0.812 * *$ & & \\
\hline \multirow{5}{*}{$\begin{array}{c}\text { IK } \\
\text { (Lai [95]; Spangenberg et } \\
\text { al. [86]; Leire and Thidell } \\
\text { [50] and Tseng and } \\
\text { Hung [85]) }\end{array}$} & $\begin{array}{l}\text { Having more information about green } \\
\text { vegetables would influence the decision to buy. }\end{array}$ & $0.831 * *$ & \multirow{5}{*}{0.771} & \multirow{5}{*}{0.537} \\
\hline & Information about green vegetables is reliable. & $0.685^{* *}$ & & \\
\hline & $\begin{array}{l}\text { The label and the packaging specifying the } \\
\text { features of green vegetables would contribute } \\
\text { to the decision to buy. }\end{array}$ & $0.733^{* *}$ & & \\
\hline & $\begin{array}{l}\text { Advertising explaining the benefits of green } \\
\text { vegetables would influence the decision to buy. }\end{array}$ & $0.820 * *$ & & \\
\hline & $\begin{array}{l}\text { Newsletters and other information about } \\
\text { environmental problems would drive the } \\
\text { consumption of green vegetables. }\end{array}$ & 0.633 & & \\
\hline
\end{tabular}

Note: GW: Greenwash; GPI: Green purchase intention; GS: Green skepticism; IK: Information and knowledge; $\lambda$ : item loading; $\alpha$ : Cronbach's alpha; AVE: Average variance extracted; $* * 0<0.01$. 
Table 2. Means, standard deviations, and correlations.

\begin{tabular}{ccccc}
\hline & GW & GPI & GS & IK \\
\hline GW & $\mathbf{0 . 8 1 1}$ & & & \\
\hline GPI & $-0.257^{* *}$ & $\mathbf{0 . 8 1 6}$ & & \\
\hline GS & $0.326^{*}$ & $-0.508^{*}$ & $\mathbf{0 . 8 0 1}$ & \\
\hline IK & $0.035^{* *}$ & $-0.054^{* *}$ & 0.021 & $\mathbf{0 . 7 3 3}$ \\
\hline M & 3.722 & 4.198 & 3.812 & 3.840 \\
\hline S.D. & 0.941 & 0.653 & 0.778 & 0.610 \\
\hline
\end{tabular}

Notes: M: Mean; S.D.: Standard deviation. The diagonal values mentioned in bold and italics represent the square root of AVE. ${ }^{*} p<0.05,{ }^{* *} p<0.01$.

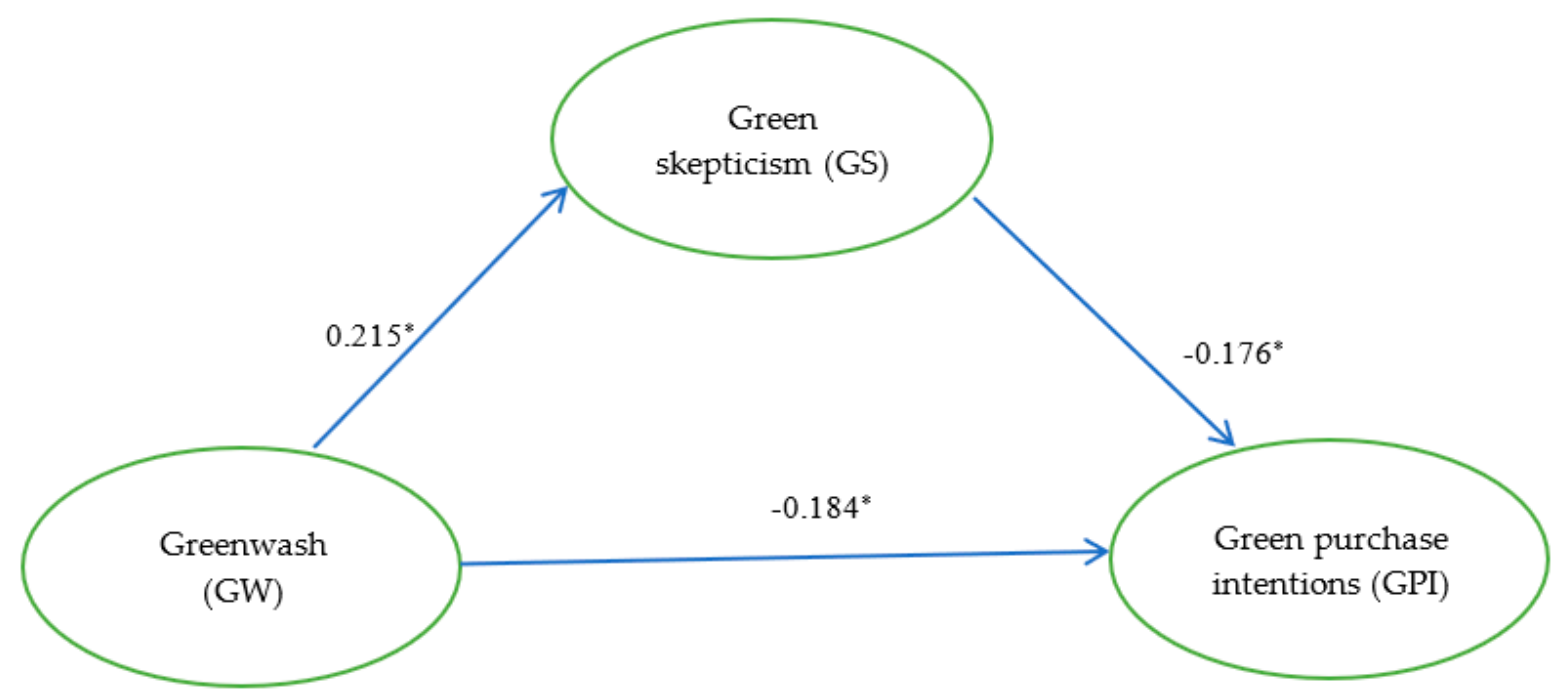

Figure 2. The results of SEM. GFI $=0.908, \mathrm{NFI}=0.934, \mathrm{CFI}=0.961, \mathrm{RMSEA}=0.045$. Notes: ${ }^{*} p<0.05$.

This study indicated how the effect of greenwash on green purchase intentions was activated through green skepticism. We implemented the bootstrap confidence intervals method with 5000 bootstrap samples [102] to confirm the mediating roles of green skepticism in the relationship between greenwash and green purchase intentions. As illustrated in Table 3, the result of the bootstrap test showed indirect effects of greenwash on green purchase intentions and has coefficient value of 0.349 with $\mathrm{p}$ value less than 0.05 . Hence, $\mathrm{H}_{4}$ is supported.

Table 3. Direct, indirect, and total effects analysis.

\begin{tabular}{cccccc}
\hline \multirow{2}{*}{ Path } & Direct Effects & Indirect Effects & Total Effects & \multicolumn{2}{c}{ Bias-Corrected Confidence Intervals } \\
\cline { 5 - 6 } & & & $\begin{array}{c}\text { Lower } \\
\text { Confidence Level }\end{array}$ & $\begin{array}{c}\text { Upper } \\
\text { Confidence Level }\end{array}$ \\
\hline $\mathbf{G W} \rightarrow \mathrm{GPI} \rightarrow \mathrm{GS}$ & $-0.178^{*}$ & $0.349^{*}$ & 0.171 & 0.169 & 0.564 \\
\hline
\end{tabular}

In addition, we performed invariance tests of the measurement model and structural model to check the moderating effect of information and knowledge [103]. Initially, the samples were divided into two as high-IK $(n=274)$ and low-IK groups $(n=145)$ with the average scores $(M=3.72)$. Subsequently, the equality between the factor loadings of both groups was examined. Confirmatory Factor Analysis (CFA) was used for both groups with and without factor loadings. Then, the results of two different models were compared. Table 4 indicates both models had good fit with the data as reflected in the fit indices as unconstrained (RMSEA $=0.034, \mathrm{CFI}=0.952$, TLI (Tucker Lewis index) $=$ 0.944 ) and full metric invariance (RMSEA $=0.034, \mathrm{CFI}=0.952, \mathrm{TLI}=0.949$ ). According to Wang and 
Wang [104], the $\chi^{2}$ difference between both models $\left(\Delta \chi^{2}(26)=32.206, p=0.264>0.05\right)$ was insignificant and the differences of CFI and TLI values between both models $(\triangle \mathrm{CFI}=0.000 \leq 0.01, \Delta \mathrm{TLI}=0.005$ $\leq 0.02$ ) confirmed little effect on the measurement structure. To sum up, full metric invariance was verified and therefore invariance test of the two-group structural model could be conducted.

Table 4. Measurement invariance test.

\begin{tabular}{cccccc}
\hline Models & $\chi^{2}$ & df & RMSEA & CFI & TLI \\
\hline Unconstrained & 292.586 & 152 & 0.034 & 0.952 & 0.944 \\
\hline Full metric invariance & 324.792 & 178 & 0.034 & 0.952 & 0.949 \\
\hline
\end{tabular}

Finally, we implemented the testing procedures for the equality of a given path of the group with a different model to assess structural invariance [103]. If the $\chi^{2}$ difference was significant, the contrast between the unconstrained and the constrained models existed. We used this test to ascertain the statistical significance of a parameter constraint in two different groups. The path coefficients from greenwash to green purchase intentions were set to be equal and other path coefficients of both high-and low-information and knowledge groups were freely estimated. As shown in Table 5 , the $\chi^{2}$ difference was significant $\left(\Delta \chi^{2}(1)=6.495^{*}, \mathrm{p}=0.016<0.05\right)$, demonstrating that the moderating effect of information and knowledge between greenwash and green purchase intentions existed. Besides, the results indicated that the coefficients estimated from greenwash and green purchase intentions were $0.568^{* *}(p<0.01)$ in the high-information and knowledge group and $0.445^{* *}(p<0.01)$ in the low-information and knowledge group. As a consequence, when consumers had a higher degree of information and knowledge on green product, the negative relationship between greenwash and green purchase intentions is strengthened. Therefore, $\mathrm{H}_{5}$ is supported.

Table 5. Invariance test of the two-group structural model.

\begin{tabular}{|c|c|c|c|c|c|c|c|}
\hline & \multicolumn{2}{|c|}{$\begin{array}{l}\text { High-IK } \\
(\mathrm{n}=274)\end{array}$} & \multicolumn{2}{|c|}{$\begin{array}{l}\text { Low-IK } \\
(n=145)\end{array}$} & \multirow{2}{*}{$\begin{array}{l}\text { Unconstrained } \\
\text { Model } \chi^{2}\end{array}$} & \multirow{2}{*}{$\begin{array}{l}\text { Constrained } \\
\text { Model } \chi 2\end{array}$} & \multirow[t]{2}{*}{$\Delta \chi^{2}$} \\
\hline & $\begin{array}{c}\text { Standardized } \\
\text { Coefficients }\end{array}$ & z-value & $\begin{array}{l}\text { Standardized } \\
\text { Coefficients }\end{array}$ & z-value & & & \\
\hline GW $\rightarrow$ GPI & 0.568 & $8.927^{* *}$ & 0.445 & $7.651 * *$ & $225.684(\mathrm{df}=134)$ & $232.179(\mathrm{df}=135)$ & 6.495 * \\
\hline
\end{tabular}

\section{Discussion}

This paper makes an important contribution to green consumption research. Nyilasy et al. [34] suggested that some industries are naturally more or less risky with regard to environmental failure, by way of consequences of consumer skepticism about green communication and activities. They also stressed the need to consider factors that may affect consumers' greenwashing cognitions/attitudes. Our research effectively addresses these points. We employ the C-A-B paradigm to understand green consumption behavior in the food industry in Vietnam, which has been facing serious environmental problems and food-related issues $[36,105,106]$. Also, we explore the mediating role of green skepticism and the moderating role of information and knowledge in the relationship between greenwash and green purchase intentions. Some new initiatives to deter greenwashing as well as grow green consumption are provided in the following paragraphs.

First, our focus on consumers' response to corporates' greenwash behavior advances current understanding of how consumer perceive food companies' environmental practices. Almost all authors agree that green business strategies have made a significant contribution to enhance corporate image. Consumers' information and knowledge on green products are relatively important for consumers in making eco-friendly purchasing decisions [50]. But the prompt increase in the green practices leads to a debate on its potential effects on environmental quality and consumers' skepticism towards companies 
that take opportunistic advantage of green trends. The current study is the first attempt to explore the greenwash-green food purchase intentions relationship in the Vietnam emerging market.

Second, apart from verification of the effect of greenwashing on green purchase intentions, this study indicates how this mechanism is activated through green skepticism. In essence, consumers are increasingly critical when evaluating food companies' environmentally sustainable practices as their awareness and experience is higher over green products. Consumers are becoming more aware of the environmental benefits, health and safety issues of purchasing green products. Consequently, they are more skeptical about companies' motives, leading to negative product judgments and lower purchase intentions from greenwashing companies. Therefore, business managers should create enough believability so that consumers do not easily become skeptical. More importantly, these firms by themselves might increase the positive image over green products under the eyes of their consumers.

The empirical findings demonstrate that the negative effect of greenwash on green purchase intentions in high-knowledge consumers would be stronger than low-knowledge ones. This might be because these consumers can distinguish between green foods and conventional foods; real green products and greenwash products. Thus, when they perceive greenwashing action, they even may stop buying green products. The purchase intentions of this group are illustrated by Holbrook and Batra [62]. High information and knowledge consumers are more strongly involved in environmental consumption. Hence, they will have extreme expectations from the eco-friendly products. If they realize a discrepancy between green advertising and corporate performance, they will have more difficulty in accepting that product. In contrast, consumers would increase the positive image over green products at their cognitive level as there are striking green initiatives.

Our findings suggest that managers should focus on multiple eco-friendly practices to develop trustworthiness in consumers' minds. The present research would encourage and support marketers to institute credible green claims that not only improve their business but also promote their environmental programs. As consumers are becoming more conscious of greenwashing behavior, managers should increase transparency of environmental performance while non-governmental organizations can audit corporate environmental reports and penalize firms that are caught appealing in greenwashing.

In summary, we recommend that firms do not only introduce strong strategies regarding their green performances but also evaluate comprehensively the marketing of those performances. Especially, green initiatives need to be certified by independent and credible agencies. Additionally, communicating green messages widely to consumers might be better strategies for companies to be more believable in the eyes of consumers as well as to avoid competitors modifying their green business strategies. In this regard, food producers need to educate retailers about their production process and green claims because such retailers are effective information channels between the producers and their consumers. Importantly, information and education programs should be collectively developed and implemented by policymakers, marketers, and social organizations to enhance consumer awareness and understanding towards green practices and the values of green products. These initiatives will improve consumers' environmental-related knowledge and ethical beliefs as well as decrease their green skepticism, hence increasing their intentions to purchase green food.

\section{Limitations and Conclusions}

Despite its important contribution to the literature, this present study has several limitations. First, we investigated Vietnamese consumers who had experience in buying green vegetables. As such, generalizability of this result is difficult. Furthermore, social desirability bias might be an issue given the nature of the present research. Thus, future studies may consist of a sample from various demographic populations that will help to recommend generalized findings. Second, this current study investigates a theoretical model which can help companies enhance consumers' green purchase intentions under the circumstance of the high number of greenwashing cases via its two determinants of green skepticism, information and knowledge. Future works could assess potential impacts of other variables like company brands, ownership type, culture context, and product category on consumers' 
reactions to greenwashing phenomenon. Third, given the various indicators of consumer information and knowledge with respect to green products (e.g., details about various benefits, features, labels), future research could use multi-criteria evaluation techniques to better explain the role of information and knowledge. Applying such evaluation techniques will comprehensively express and address the multidimensional character of the examined construct [107].

Recently, consumers have become more interested in environmental, health and safety issues. They are normally attracted to green foods as well as the greenwashing phenomenon in the food industry. Though numerous past research examined this phenomenon in sustainable marketing, it remains fairly under researched in the food industry in emerging markets. Hence, the study fills a gap in the literature. By employing the C-A-B paradigm as a theoretical foundation, this study investigates the mediation effects of green skepticism as well as the moderating effects of information and knowledge on the relationship between greenwash and green purchase intentions. The findings indicated that the corporates' greenwash action triggered consumer skepticism of the green food's claims, and as a result, it affects the green purchase intentions. In addition, the negative effect of greenwash on green purchase intentions would be weaker or stronger depending on the level of consumers' information and knowledge. Therefore, companies should diversify their green practices and continue to develop a positive green image. These initiatives will reduce consumer skepticism about the companies' green practices and claims, leading to an increase in purchase intention towards green food.

Author Contributions: Conceptualization, T.T.H.N., Z.Y., N.N., L.W.J. and T.K.C.; methodology, T.T.H.N. and Z.Y.; formal analysis, T.T.H.N. and Z.Y.; investigation, T.T.H.N.; writing一original draft preparation, T.T.H.N., Z.Y., N.N., L.W.J. and T.K.C.; writing-review and editing, T.T.H.N., N.N. and L.W.J.; supervision, Z.Y.

Funding: This research was funded by the Soft Science Key Project of Hunan Province, grant number HNSSKP (2017ZK3054).

Conflicts of Interest: The authors declare no conflict of interest.

\section{References}

1. Marchand, A.; Walker, S. Product development and responsible consumption: Designing alternatives for sustainable lifestyles. J. Clean. Prod. 2008, 16, 1163-1169. [CrossRef]

2. Leonidou, C.N.; Skarmeas, D. Gray shades of green: Causes and consequences of green skepticism. J. Bus. Ethics 2015, 144, 401-415. [CrossRef]

3. Guo, R.; Tao, L.; Li, C.B.; Wang, T. A path analysis of greenwashing in a trust crisis among chinese energy companies: The role of brand legitimacy and brand loyalty. J. Bus. Ethics 2017, 140, 523-536. [CrossRef]

4. Stephenson, E.; Doukas, A.; Shaw, K. Greenwashing gas: Might a 'transition fuel' label legitimize carbon-intensive natural gas development? Energy Policy 2012, 46, 452-459. [CrossRef]

5. Smith, V.L.; Font, X. Volunteer tourism, greenwashing and understanding responsible marketing using market signalling theory. J. Sustain. Tour. 2014, 22, 942-963. [CrossRef]

6. Siano, A.; Vollero, A.; Conte, F.; Amabile, S. "More than words": Expanding the taxonomy of greenwashing after the volkswagen scandal. J. Bus. Res. 2017, 71, 27-37. [CrossRef]

7. Chen, Y.S.; Chang, C.H. Enhance green purchase intentions: The roles of green perceived value, green perceived risk, and green trust. Manag. Decis. 2012, 50, 502-520. [CrossRef]

8. Jonsen, K.; Galunic, C.; Weeks, J.; Braga, T. Evaluating espoused values: Does articulating values pay off? Eur. Manag. J. 2015, 33, 332-340. [CrossRef]

9. Rahman, I.; Park, J.D.; Chi, G.Q.C. Consequences of "greenwashing": Consumer's reactions to hotel's green initiatives. Int. J. Contemp. Hosp. Manag. 2015, 27, 1054-1081. [CrossRef]

10. Aras, G.; Crowther, D. Corporate sustainability reporting: A study in disingenuity? J. Bus. Ethics 2009, 87, 279. [CrossRef]

11. Husted, B.W.; Allen, D.B. Strategic corporate social responsibility and value creation: A study of multinational enterprises in mexico. Manag. Int. Rev. 2009, 49, 781-799. [CrossRef]

12. Nelson, G.C.; Robertson, R.D. Green gold or green wash: Environmental consequences of biofuels in the developing world. Rev. Agric. Econ. 2010, 30, 517-529. [CrossRef] 
13. Kim, E.H.; Lyon, T.P. Strategic environmental disclosure: Evidence from the doe's voluntary greenhouse gas registry . J. Environ. Econ. Manag. 2011, 61, 311-326. [CrossRef]

14. Kim, E.H.; Lyon, T.P. Greenwash vs. Brownwash: Exaggeration and Undue Modesty in Corporate Sustainability Disclosure. Organization Science. 2015, 26, 705-723. [CrossRef]

15. Relaño, F. Maximizing social return in the banking sector. Corp. Gov. Int. J. Bus. Soc. 2011, 11, $274-284$. [CrossRef]

16. Wang, Z.; Sarkis, J. Corporate social responsibility governance, outcomes, and financial performance. J. Clean. Prod. 2017, 162, 1607-1616. [CrossRef]

17. Font, X.; Walmsley, A.; Cogotti, S.; Mccombes, L.; Häusler, N. Corporate social responsibility: The disclosure-performance gap. Tour. Manag. 2012, 33, 1544-1553. [CrossRef]

18. Chan, E.S.W. Managing green marketing: Hong kong hotel managers' perspective. Int. J. Hosp. Manag. 2013, 34, 442-461. [CrossRef]

19. Geerts, W. Environmental certification schemes: Hotel managers' views and perceptions. International J. Hosp. Manag. 2014, 39, 87-96. [CrossRef]

20. Jones, D.R. Looking through the "greenwashing glass cage" of the green league table towards the sustainability challenge for UK universities. J. Organ. Chang. Manag. 2012, 25, 630-647. [CrossRef]

21. Chen, Y.S.; Chang, C.H. Greenwash and green trust: The mediation effects of green consumer confusion and green perceived risk. J. Bus. Ethics 2013, 114, 489-500. [CrossRef]

22. Chen, Y.S.; Lin, C.L.; Chang, C.H. The influence of greenwash on green word-of-mouth (green wom): The mediation effects of green perceived quality and green satisfaction. Qual. Quant. 2014, 48, 2411-2425. [CrossRef]

23. Chen, Y.S.; Tien, W.P.; Lee, Y.I.; Tsai, M.L. Greenwash and green brand equity. In Proceedings of the International Conference on Management of Engineering and Technology, Portland, OR, USA, 9-13 July 2017; pp. 1797-1803.

24. Chen, Y.S.; Chang, C.H. Towards green trust: The influences of green perceived quality, green perceived risk, and green satisfaction. Manag. Decis. 2013, 51, 63-82. [CrossRef]

25. Aji, H.M.; Sutikno, B. The extended consequence of greenwashing: Perceived consumer skepticism. Int. J. Bus. Inf. 2015, 10, 433-468.

26. Albayrak, T.; Caber, M.; Aksoy, Ş. The effect of environmental concern and scepticism on green purchase behaviour. Mark. Intell. Plan. 2013, 31, 27-39. [CrossRef]

27. Blome, C.; Kai, F.; Schleper, M.C. Antecedents of green supplier championing and greenwashing: An empirical study on leadership and ethical incentives. J. Clean. Prod. 2017, 152, 339-350. [CrossRef]

28. Bowen, F.; Aragon-Correa, J.A. Greenwashing in corporate environmentalism research and practice: The importance of what we say and do. Organ. Environ. 2014, 27, 107-112. [CrossRef]

29. Dahl, R. Green washing: Do you know what you're buying? Environ. Health Perspect. 2010, 118, A246. [CrossRef]

30. Delmas, M.A.; Burbano, V.C. The drivers of greenwashing. Calif. Manag. Rev. 2011, 54, 64-87. [CrossRef]

31. Du, X. How the market values greenwashing? Evidence from china. J. Bus. Ethics 2015, 128, 547-574. [CrossRef]

32. Gillespie, E. Stemming the tide of 'greenwash'. Consum. Policy Rev. 2008, 18, 78-93.

33. Horiuchi, R.; Schuchard, R.; Shea, L.; Townsend, S. Understanding and Preventing Greenwash: A Business Guide; Business for Social Responsibility: London, UK, 2009.

34. Nyilasy, G.; Gangadharbatla, H.; Paladino, A. Perceived greenwashing: The interactive effects of green advertising and corporate environmental performance on consumer reactions. J. Bus. Ethics 2014, 125, 693-707. [CrossRef]

35. Van Huy, L.; Chi, M.T.T.; Lobo, A.; Nguyen, N.; Long, P.H. Effective segmentation of organic food consumers in vietnam using food-related lifestyles. Sustainability. Sustainability 2019, 11, 1237. [CrossRef]

36. Nguyen, H.V.; Nguyen, N.; Nguyen, B.K.; Lobo, A.; Vu, P.A. Organic food purchases in an emerging market: The influence of consumers' personal factors and green marketing practices of food stores. Int. J. Environ. Res. Publich Health 2019, 16, 1037. [CrossRef] [PubMed]

37. World Bank. Data-Vietnam. Available online: http://data.worldbank.org/country/vietnam (accessed on 30 April 2019). 
38. General Statistics Office of Vietnam. Vietnam Household Living Standards Survey 2012; GSO: Hanoi, Vietnam, 2014.

39. Wertheim-Heck, S.C.O.; Spaargaren, G. Shifting configurations of shopping practices and food safety dynamics in hanoi, vietnam: A historical analysis. Agric. Hum. Values 2016, 33, 655-671. [CrossRef]

40. Chau, H.L.Q.; Thong, H.T.; Chao, N.V.; Hung, P.H.S.; Hai, V.V.; Le, V.A.; Fujieda, A.; Ueru, T.; Akamatsu, M. Microbial and parasitic contamination on fresh vegetables sold in traditional markets in hue city, vietnam. J. Food Nutr. Res. 2014, 2, 959-964. [CrossRef]

41. Ha, N.T.; Kitajima, M.; Hang, N.V.; Matsubara, K.; Takizawa, S.; Katayama, H.; Oguma, K.; Ohgaki, S. Bacterial contamination of raw vegetables, vegetable-related water and river water in ho chi minh city, vietnam. Water Sci. Technol. 2008, 58, 2403.

42. Le, T.H.H.; Nguyen, T.Q.H.; Cao, S.T.; Vu, T.T.; Nguyen, T.L.; Cao, V.H.; Ta, T.T.; Pham, T.N.M.; Nguyen, T.A.H.; Mai, T.D. Screening determination of food additives using capillary electrophoresis coupled with contactless conductivity detection: A case study in vietnam. Food Control 2017, 77, 281-289. [CrossRef]

43. Nguyen, T.N.; Lobo, A.; Nguyen, B.K. Young consumers' green purchase behaviour in an emerging market. J. Strateg. Mark. 2018, 26, 583-600. [CrossRef]

44. Pham, T.H.; Nguyen, T.N.; Phan, T.T.H.; Nguyen, N.T. Evaluating the purchase behaviour of organic food by young consumers in an emerging market economy. J. Strateg. Mark. 2018. [CrossRef]

45. Thien Nhien. Available online: https://www.thiennhien.net/2018/08/15/thi-truong-thuc-pham-huu-co-cungcau-chua-gap-nhau/ (accessed on 30 April 2019).

46. Cafebiz. Available online: http://cafebiz.vn/thuc-pham-gan-mac-sach-co-thuc-su-sach-20160604144752074. chn (accessed on 30 April 2019).

47. Lyon, T.P.; Maxwell, J.W. Greenwash: Corporate environmental disclosure under threat of audit. J. Econ. Manag. Strategy 2011, 20, 3-41. [CrossRef]

48. Lyon, T.P.; Montgomery, A.W. Tweetjacked: The impact of social media on corporate greenwash. J. Bus. Ethics 2013, 118, 747-757. [CrossRef]

49. Lyon, T.P.; Montgomery, A.W. The means and end of greenwash. Organ. Environ. 2015, 28, 21-36. [CrossRef]

50. Leire, C.; Thidell, Å. Product-related environmental information to guide consumer purchases-A review and analysis of research on perceptions, understanding and use among nordic consumers. J. Clean. Prod. 2005, 13, 1061-1070. [CrossRef]

51. Garnett, T. Cooking up a Storm: Food, Greenhouse Gas Emissions and Our Changing Climate; Food Climate Research Network: Guildford, UK, 2008.

52. Maloni, M.J.; Brown, M.E. Corporate social responsibility in the supply chain: An application in the food industry. J. Bus. Ethics 2006, 68, 35-52. [CrossRef]

53. Torugsa, N.A.; O'Donohue, W.; Hecker, R. Proactive csr: An empirical analysis of the role of its economic, social and environmental dimensions on the association between capabilities and performance. J. Bus. Ethics 2013, 115, 383-402. [CrossRef]

54. Mitchell, V.W.; Papavassiliou, V. Marketing causes and implications of consumer confusion. J. Prod. Brand Manag. 1999, 8, 319-342. [CrossRef]

55. Smart, B. Beyond Compliance-A New Industry View of the Environment; World Resources Institute: Washington, DC, USA 1992.

56. Hamilton, S.F.; Zilberman, D. Green markets, eco-certification, and equilibrium fraud. J. Environ. Econ. Manag. 2006, 52, 627-644. [CrossRef]

57. Cho, C.H.; Patten, D.M. The role of environmental disclosures as tools of legitimacy: A research note. Account. Organ. Soc. 2007, 32, 639-647. [CrossRef]

58. Henriques, I.; Husted, B.W.; Montiel, I. Spillover effects of voluntary environmental programs on greenhouse gas emissions: Lessons from mexico. J. Policy Anal. Manag. 2013, 32, 296-322. [CrossRef]

59. Saunders, M.; Lewis, P.; Thornhill, A. Research Methods for Business Students; Pearson: Harlow, UK, 2016.

60. Nicosia, F.M.A. Consumer Decision Processes: Marketing and Advertising Implications; Prentice-Hall: Upper Saddle River, NJ, USA, 1966.

61. Howard, J.A.; Sheth, J.N. The Theory of Buyer Behavior; Wiley: New York, NY, USA, 1969.

62. Holbrook, M.B.; Batra, R. Assessing the role of emotions as mediators of consumer responses to advertising. J. Consum. Res. 1987, 14, 404-420. [CrossRef] 
63. Laroche, M.; Hui, M.; Zhou, L. A test of the effects of competition on consumer brand selection processes. J. Bus. Res. 2004, 31, 171-181. [CrossRef]

64. Fiore, A.M.; Kim, J. An integrative framework capturing experiential and utilitarian shopping experience. Int. J. Retail Distrib. Manag. 2007, 35, 421-442. [CrossRef]

65. Roseman, I.J. Cognitive Determinants of Emotions; Yale University: New Haven, CT, USA, 1982.

66. Lazarus, R.S. Emotion and Adaptation; Oxford University Press: New York, NY, USA, 1991.

67. Holbrook, M.B. Emotions in the consumption experience: Toward a new model of consumer behavior. In The Role of Affect in Consumer Behavior: Emerging Theories and Applications, Heath; Peterson, R.A., Hoyer, W.D., Wilson, W.R., Eds.; Free Press: Lexington, MA, USA, 1986; pp. 17-52.

68. Wang, H.; Moustier, P.; Loc, N.T.T. Economic impact of direct marketing and contracts: The case of safe vegetable chains in northern vietnam. Food Policy 2014, 47, 13-23. [CrossRef]

69. Yiridoe, E.K.; Bonti-Ankomah, S.; Martin, R.C. Comparison of consumer perceptions and preference toward organic versus conventional produced foods: A review and update of the literature. Renew. Agric. Food Syst. 2005, 20, 193-205. [CrossRef]

70. Nuttavuthisit, K.; Thøgersen, J. The importance of consumer trust for the emergence of a market for green products: The case of organic food. J. Bus. Ethics 2017, 140,1-15. [CrossRef]

71. Self, R.M.; Self, D.R.; Bell-Haynes, J. Marketing tourism in the galapagos islands: Ecotourism or greenwashing? Int. Bus. Econ. Res. J. 2010, 9, 111-125. [CrossRef]

72. Polonsky, M.J.; Grau, S.L.; Garma, R. The new greenwash? Potential marketing problems with carbon offsets. Int. J. Bus. Stud. 2010, 18, 49-54.

73. Ramus, C.A.; Montiel, I. When are corporate environmental policies a form of greenwashing? Bus. Soc. 2005, 44, 377-414. [CrossRef]

74. Boush, D.M.; Friestad, M.; Rose, G.M. Adolescent skepticism toward tv advertising and knowledge of advertiser tactics. J. Consum. Res. 1994, 21, 165-175. [CrossRef]

75. Forehand, M.R.; Grier, S. When is honesty the best policy? The effect of stated company intent on consumer skepticism. J. Consum. Psychol. 2003, 13, 349-356.

76. TerraChoice. The Seven Sins of Greenwashing; TerraChoice Environmental Marketing Inc.: Ottawa, ON, Canada, 2009.

77. Vindigni, G.; Janssen, M.A.; Jager, W. Organic food consumption: A multi-theoretical framework of consumer decision making. Br. Food J. 2002, 104, 624-642. [CrossRef]

78. Bhattacharya, S. Consumer attitude towards green marketing in India. Iup J. Mark. Manag. 2012, 10, 62-71.

79. Schlegelmilch, B.B.; Bohlen, G.M.; Diamantopoulos, A. The link between green purchasing decisions and measures of environmental consciousness. Eur. J. Mark. 2013, 30, 35-55. [CrossRef]

80. Wong, V.; Turner, W.; Stoneman, P. Marketing strategies and market prospects for environmentally-friendly consumer products. Br. J. Manag. 1996, 7, 263-281. [CrossRef]

81. Obermiller, C.; Spangenberg, E.; Maclachlan, D.L. Ad skepticism: The consequences of disbelief. J. Advert. 2005, 34, 7-17. [CrossRef]

82. Pomering, A.; Johnson, L.W. Advertising corporate social responsibility initiatives to communicate corporate image. Corp. Commun. 2009, 14, 420-439. [CrossRef]

83. Paço, A.d.; Alves, H.; Shiel, C.; Filho, W.L. Development of a green consumer behaviour model. Int. J. Consum. Stud. 2013, 37, 414-421. [CrossRef]

84. Gleim, M.R.; Smith, J.S.; Andrews, D.; Cronin, J.J., Jr. Against the green: A multi-method examination of the barriers to green consumption. J. Retail. 2013, 89, 44-61. [CrossRef]

85. Tseng, S.-C.; Hung, S.-W. A framework identifying the gaps between customers' expectations and their perceptions in green products. J. Clean. Prod. 2013, 59, 174-184. [CrossRef]

86. Spangenberg, J.H.; Fuad-Luke, A.; Blincoe, K. Design for sustainability (dfs): The interface of sustainable production and consumption. J. Clean. Prod. 2010, 18, 1485-1493. [CrossRef]

87. Jensen, M.; Sörensen, S.; Schmidt, A.; Grinderslev, M.; Hjelmar, U. Forbrugernes Muligheder og Interesse for Køb af Grøn Elektronik; Miljøstyrelsen: Copenhagen, Denmark, 2002.

88. Neergaard, P.; Andersen, M.; Bech, L. Environmental-Friendly Textiles; Copenhagen Business School: Miljo styrelsen, Denmark, 2002.

89. Laufer, W.S. Social accountability and corporate greenwashing. J. Bus. Ethics 2003, 43, 253-261. [CrossRef] 
90. Mohr, L.A.; Eroǧlu, D.; Ellen, P.S. The development and testing of a measure of skepticism toward environmental claims in marketers' communications. J. Consum. Aff. 1998, 32, 30-55. [CrossRef]

91. Ajzen, I.; Fishbein, M. Understanding Attitudes and Predicting Social Behavior; Prentice-Hall: Upper Saddle River, NJ, USA, 1980.

92. Taylor, S.; Todd, P. Decomposition and crossover effects in the theory of planned behavior: A study of consumer adoption intentions. Int. J. Res. Mark. 1995, 12, 137-155. [CrossRef]

93. Mostafa, M.M. Antecedents of egyptian consumers' green purchase intentions. J. Int. Consum. Mark. 2006, 19, 97-126. [CrossRef]

94. Chen, C.F.; Chang, Y.Y. Airline brand equity, brand preference, and purchase intentions-The moderating effects of switching costs. J. Air Transp. Manag. 2008, 14, 40-42. [CrossRef]

95. Lai, O.-K. Making sense of the greening of consumption and production. J. Clean. Prod. 1993, 1, 43-47. [CrossRef]

96. Hair, J.; Black, W.; Babin, B.; Anderson, R. Multivariate Data Analysis, 7th ed.; Prentice Hall: Upper Saddle River, NJ, USA, 2010.

97. Baumgartner, H.; Homburg, C. Applications of structural equation modeling in marketing and consumer research: A review. Int. J. Res. Mark. 1996, 13, 139-161. [CrossRef]

98. Peter, J.P. Reliability: A review of psychometric basics and recent marketing practices. J. Mark. Res. 1979, 16, 6-17. [CrossRef]

99. Hair, J.F.; Anderson, R.E.; Tatham, R.L.; Black, W.C. Multivariate Data Analysis; Prentice-Hall: Upper Saddle River, NJ, USA, 1998.

100. Fornell, C.; Larcker, D.F. Evaluating structural equation models with unobservable variables and measurement error. J. Mark. Res. 1981, 18, 39-50. [CrossRef]

101. Bagozzi, R.P.; Yi, Y. On the evaluation of structural equation models. J. Acad. Mark. Sci. 1988, 16, 74-94. [CrossRef]

102. Preacher, K.J.; Hayes, A.F. Asymptotic and resampling strategies for assessing and comparing indirect effects in multiple mediator models. Behav. Res. Methods 2008, 40, 879-891. [CrossRef] [PubMed]

103. Liu, X.M.; Li, J.J.; Yang, Y. Travel arrangement as a moderator in image-satisfaction-behavior relations: An investigation of chinese outbound travelers. J. Vac. Mark. 2015, 21, 1243-1245.

104. Wang, J.; Wang, X. Structural Equation Modeling: Applications Using Mplus; Wiley Publishing: Hoboken, NJ, USA, 2012; pp. 465-486.

105. Nguyen, T.N.; Lobo, A.; Greenland, S. The influence of vietnamese consumers' altruistic values on their purchase of energy efficient appliances. Asia Pac. J. Mark. Logist. 2017, 29, 759-777. [CrossRef]

106. Nguyen, T.N.; Phan, T.T.H.; Cao, T.K.; Nguyen, T.N.; Nguyen, T.N.; Nguyen, T.N.; Nguyen, T.N.; Nguyen, T.N.; Nguyen, H.V. Green purchase behavior: Mitigating barriers in developing countries. Strateg. Dir. 2017, 33, 4-6. [CrossRef]

107. Nesticò, A.; Guarini, M.R.; Morano, P.; Sica, F. An economic analysis algorithm for urban forestry projects. Sustainability 2019, 11, 314. [CrossRef]

(C) 2019 by the authors. Licensee MDPI, Basel, Switzerland. This article is an open access article distributed under the terms and conditions of the Creative Commons Attribution (CC BY) license (http://creativecommons.org/licenses/by/4.0/). 